\title{
Quantification and clinical relevance of gene amplification at chromosome 17q12-q21 in human epidermal growth factor receptor 2-amplified breast cancers
}

Pierre-Jean Lamy ${ }^{1 *}$, Frédéric Fina ${ }^{2}$, Caroline Bascoul-Mollevi ${ }^{3}$, Anne-Claire Laberenne ${ }^{1}$, Pierre-Marie Martin², $\mathrm{L}^{\prime}$ Houcine Ouafik ${ }^{2,4}$, William Jacot $^{5}$

\begin{abstract}
Introduction: Human epidermal growth factor receptor 2 (HER2)-amplified breast cancers represent a tumor subtype with chromosome 17q rearrangements that lead to frequent gene amplifications. The aim of this study was to quantify the amplification of genes located on chromosome $17 q$ and to analyze the relations between the pattern of gene amplifications and the patients' characteristics and survival.

Methods: Patients with HER2-positive breast tumors (HER2 score of 3+ by immunohistochemistry or positive for HER2 amplification by fluorescence in situ hybridization (FISH)) $(n=86)$ and with HER2-negative breast tumors $(n=40)$ (negative controls) were included in this study. Using a quantitative polymerase chain reaction method and DNA extracted from frozen tumor specimens, 11 genes (MED1, STARD3, HER2, GRB7, THRA, RARA, TOP2A, IGFBP4, CCR7, KRT20, KRT19 and GAS), which are localized within Chr17q12-q21 and have a putative role in breast cancer development, were quantified. Relapse-free and overall survival rates were estimated from the date of surgery to the date of the event of interest (recurrence or death) using the Kaplan-Meier method.

Results: Gene amplification was observed only in HER2-positive tumors, and the frequency of amplification decreased with the distance of the gene from HER2. HER2 presented the highest level of amplification. TOP2A was not included in the smallest region of amplification involving HER2. Amplification of RARA, KRT20 and KRT19 was significantly associated with node-positive breast cancer $(P=0.030, P=0.002$ and $P=0.033$, respectively). During a median follow-up period of 55 months (range, 6 to 81 months), the subgroup of patients with hormone receptornegative cancer and without TOP2A amplification showed the worst survival (relapse-free survival: hazard ratio $(H R)=0.29,95 \%$ confidence interval $(95 \% C l), 0.13$ to $0.65, P=0.001$; and overall survival: $\mathrm{HR}=0.28,95 \% \mathrm{Cl}, 0.10$ to $0.76, P=0.008)$.
\end{abstract}

Conclusions: HER2 amplification seems to drive genomic instability along chromosome $17 \mathrm{q}$, leading to different patterns of gene amplification. This study confirms the clinical importance of identifying, among patients with HER2-positive breast tumors, the subgroup of patients with hormone receptor-negative and nonamplified TOP2A cancers as they have the worst prognosis.

\footnotetext{
* Correspondence: pjlamy@valdorel.fnclcc.fr

'Laboratoire de Biologie Spécialisée et d'Oncogénétique, Centre Régional de Lutte contre le Cancer Val d'Aurelle-Paul Lamarque, 208, rue des

Apothicaires, Montpellier F-34298, France

Full list of author information is available at the end of the article
} 


\section{Introduction}

Gene amplification at chromosome 17q (Chr17q) involves the human epidermal growth factor receptor 2 (HER2) gene and is observed in about $15 \%$ to $20 \%$ of breast cancers. HER2 amplification is associated with aggressive tumor behavior (increased metastatic potential and reduced survival), and it also predicts a patient's response to trastuzumab therapy [1,2]. Although HER2-positive breast cancers are classified as a tumor subgroup, they are quite heterogeneous. Indeed, they can be divided more or less equally into hormone receptor-negative (estrogen receptor/progesterone receptor-negative, or ER/ $\mathrm{PR}$-negative) and hormone receptor-positive (ER/PR-positive) tumors. In the ER/PR-positive subgroup, development of resistance to antihormonal therapy could be explained by the cross-talk between the HER2 and ER pathways [3]. Furthermore, first-line treatment of HER2positive breast cancers with trastuzumab presents response rates that vary between $25 \%$ and $35 \%$, and the benefit of trastuzumab therapy has been shown only in patients with high levels of HER2 amplification [4]. Comparative genomic hybridization arrays and fluorescence in situ hybridization (FISH) studies have shown that HER2amplified breast cancers present a variety of alterations on Chr17 and gene amplifications at Chr17q12-q21 are particularly frequent and complex [5]. Among the genes that are located in this region and have been reported to be amplified in breast cancers, topoisomerase II $\alpha$ $(T O P 2 A)$, a gene coding for the enzyme targeted by anthracyclines, is located $2 \mathrm{Mb}$ from HER2. TOP $2 A$ amplification might be linked to the sensitivity to anthracyclines observed in HER2-positive breast tumors [6-18]. Most of the published data indicate that TOP2A amplification occurs only in HER2-amplified tumors. However, some authors have reported cases in which TOP2A was amplified also in the absence of HER2 amplification $[19,20]$. Interestingly, the same studies do not support the role of TOP $2 A$ amplification as a predictive marker for response to anthracyclines. These works also report a different frequency of TOP2A amplifications and deletions. The presence of TOP $2 A$ deletions, often analyzed together with $T O P 2 A$ amplification, has complicated the question of the relations among TOP $2 A$ alteration, prognosis and response to anthracyclines. Technical issues, the cutoff levels used to classify a gene as amplified or deleted and different quality assurance guidelines could also explain these discrepancies $[21,22]$.

Nevertheless, the molecular variations within the Chr17q amplicon and their clinical implications remain largely unknown. Indeed, besides TOP2A, other genes which are located not only in the HER2 smallest region of amplification (SRA) $[23,24]$ but also all along the long arm of the Chr17 [5,24-27] might also be amplified, and they could play functional roles in breast cancer development and progression. To explore this hypothesis, we carried out a quantitative analysis of a set of 11 genes that were chosen for their localization along Chr17q12q21 and for their putative role in breast cancer development. Two genes were located on the centromeric side (MED1 and STARD3), and nine were located on the distal side (GRB7, THRA, RARA, TOP2A, IGFBP4, CCR7, KRT20, KRT19 and GAS) of Ch17q12-21 relative to HER2 localization. The relation between gene amplification and patients' characteristics and survival was then analyzed. We show that amplification of TOP $2 A$ and of other genes distal to HER2 does not occur in tumors in which HER2 is not amplified. We confirm that TOP2A is not included in the SRA involving HER2 and describe different copy number alterations along the distal side of Chr17q. We also show that TOP2A nonamplification is related to worse survival in the subpopulation patients with of ER/PR-negative tumors.

\section{Materials and methods}

\section{Patients' characteristics, tumor samples and treatment}

A total of 759 consecutive breast cancer patients referred to the Val d'Aurelle Cancer Center between March 2002 and May 2005 were prospectively entered into the database of a tumor DNA bank. Ethical approval was provided by the local research ethics committee. All patients gave their written, informed consent. The DNA bank was created using frozen, histologically proven invasive breast cancer specimens that were primarily handled for ER testing by the dextran charcoal method. Patients with primary HER2-positive breast cancer were initially selected on the basis of the level of HER2 expression by immunohistochemistry (IHC) using the HercepTest (DakoCytomation, Trappes, France). HER2 scores of 0 and 1 were considered negative. HER2 scores of 2+ were then checked by FISH for HER2 copy number (PathVysion HER-2 DNA Probe Kit; Abbott Molecular, Rungis, France). Only patients with HER2 scores of $3+$ derived by IHC or positive for HER2 amplification by FISH were considered HER2-positive. HER 2 copy number and Chr17 polysomy were then assessed by quantitative polymerase chain reaction (qPCR) as previously described [28]. Patients presenting with Chr17 polysomy without true HER2 amplification were excluded from the study. Adjuvant treatment was discussed in multidisciplinary medical meetings according to local and international guidelines and submitted for each patient's approval. All patients were treated at least by adjuvant radiation therapy and received anthracyclinebased adjuvant therapy according to the medical standards at the time of diagnosis. Considering the patient accrual period, and despite their HER2-positive status, women were not treated with adjuvant anti-HER2 therapy, with 
the exception of patients included in a clinical trial to assess the benefits of trastuzumab as adjuvant therapy. The clinicopathologic characteristics and treatments are summarized in Table 1. Patients received regular followup examinations, that is, every 6 months for the first 5 years, then yearly after that.

\section{DNA extraction and gene quantification}

Each frozen tumor specimen was pulverized in liquid nitrogen with an automatic grinder (Cryobroyeur 2000P

\section{Table 1 Patients' characteristics ${ }^{a}$}

\begin{tabular}{|c|c|}
\hline Characteristic & $\begin{array}{l}\text { Number of patients (\%) } \\
(n=86)\end{array}$ \\
\hline \multicolumn{2}{|l|}{ Age, yr } \\
\hline$<50$ & 33 (38.4\%) \\
\hline$\geq 50$ & $53(61.6 \%)$ \\
\hline \multicolumn{2}{|l|}{$\mathrm{T}$} \\
\hline 1 & $35(40.7 \%)$ \\
\hline 2 & $46(53.5 \%)$ \\
\hline 3 & $4(4.6 \%)$ \\
\hline 4 & $1(1.2 \%)$ \\
\hline \multicolumn{2}{|l|}{ N } \\
\hline $\mathrm{N}^{+}$ & 51 (59.3\%) \\
\hline $\mathrm{N}^{-}$ & $35(40.7 \%)$ \\
\hline \multicolumn{2}{|l|}{ SBR } \\
\hline 2 & $36(42.3 \%)$ \\
\hline 3 & $49(57.7 \%)$ \\
\hline Missing & 1 \\
\hline \multicolumn{2}{|l|}{ Hormone receptor status } \\
\hline \multicolumn{2}{|l|}{ ER } \\
\hline$E R^{-}$ & $60(69.8 \%)$ \\
\hline $\mathrm{ER}^{+}$ & $26(30.2 \%)$ \\
\hline \multicolumn{2}{|l|}{ PR } \\
\hline $\mathrm{PR}^{-}$ & $44(51.2 \%)$ \\
\hline $\mathrm{PR}^{+}$ & $42(48.8 \%)$ \\
\hline \multicolumn{2}{|l|}{$E R / P R$} \\
\hline$E R^{-} / P R^{-}$ & $42(48.9 \%)$ \\
\hline $\mathrm{ER}^{-} / \mathrm{PR}^{+}$ & $18(20.9 \%)$ \\
\hline $\mathrm{ER}^{+} / \mathrm{PR}^{-}$ & $2(2.3 \%)$ \\
\hline $\mathrm{ER}^{+} / \mathrm{PR}^{+}$ & $24(27.9 \%)$ \\
\hline \multicolumn{2}{|l|}{ Treatment } \\
\hline \multicolumn{2}{|l|}{ Chemotherapy } \\
\hline Anthracyclines & $42(48.8 \%)$ \\
\hline Anthracyclines and taxanes & $26(30.2 \%)$ \\
\hline No chemotherapy & $18(21.0 \%)$ \\
\hline Radiation therapy & $86(100.0 \%)$ \\
\hline Antihormone therapy & $34(39.5 \%)$ \\
\hline Trastuzumab & $20(23.3 \%)$ \\
\hline \multicolumn{2}{|l|}{ Outcomes } \\
\hline Recurrence & $25(29.1 \%)$ \\
\hline Death & $17(20.0 \%)$ \\
\hline
\end{tabular}

${ }^{\mathrm{a}} \mathrm{T}$, tumor size; $\mathrm{N}$, lymph node status; SBR, Scarff-Bloom-Richardson histological grade; $E R$, estrogen receptor; $P R$, progesterone receptor.
Automatique; Rivoire, Montpellier, France), homogenized in a Polytron homogenizer in buffer $(20 \mathrm{mM}$ Tris $\mathrm{HCI}, 1.5 \mathrm{mM}$ ethylenediaminetetraacetic acid (EDTA), $10 \mathrm{mM} \mathrm{Na} 2 \mathrm{MoO}_{4}, 1.5 \mathrm{mM}$ dithiothreitol and $10 \%$ glycerol, pH 7.4) (buffer:tissue ratio was 10:1 (vol/wt)) used for ER and PR measurement and centrifuged at 10,000 $\times g$ for 15 minutes. Total genomic DNA was extracted from the pellet. The DNA concentration was determined by measuring the absorbance at $260 \mathrm{~nm}$, and all samples had a 260/280-nm ratio higher than 1.7. DNA was stored at $-20^{\circ} \mathrm{C}$ in TE buffer $(10 \mathrm{mM}$ Tris and $0.5 \mathrm{mM}$ EDTA, pH 7.6). All procedures were carried out at $4^{\circ} \mathrm{C}$ unless noted otherwise. qPCR amplifications were performed with $10 \mathrm{ng}$ of DNA on a Rotorgene 6000 apparatus (Qiagen, Courtaboeuf, France) using ABsolute Blue qPCR SYBR Green Mix (ref AB-4167; ThermoFisher Scientific, Illkirch, France) with an initial 15 -minute denaturation step at $95^{\circ} \mathrm{C}$ followed by 40 cycles. The cycling temperatures and the primers used for each gene are summarized in Table 2. After completion of the amplification, samples were subjected to a temperature ramp (from the annealing temperature to $95^{\circ} \mathrm{C}$ with a transition rate of $0.1^{\circ} \mathrm{C} / \mathrm{s}$ ) with continuous fluorescence monitoring for melting curve analysis. MED1, STARD3, HER2, GRB7, THRA, RARA, TOP2A, IGFBP4, CCR7, KRT20, KRT19 and GAS amplification levels were normalized to those of the somatostatin receptor type II (SSTR2) gene that is localized on Chr17q24. HER2 quantification was also normalized to the expression values of glyceraldehyde 3-phosphate dehydrogenase (GAPDH), which is localized on chromosome $12 \mathrm{p} 13$, and of $\beta$-actin $(A C B T)$, which is localized on chromosome $7 \mathrm{p} 22$, as controls for polysomy. SSTR2 quantification was also normalized to GAPDH and $A C B T$ to detect SSTR2 amplification. Quantification was obtained by constructing a standard curve from serial dilutions of normal genomic DNA (ref 11691112 001; Roche, Meylan, France). For HER2 amplification, genomic DNA from SKBR3 cells was used as a positive control and DNA from MCF-7 cells was used as a negative control. Water was used as a negative control for PCR contamination. A gene was considered to be amplified when the target gene-to-reference gene ratio was $\geq 2$, and it was considered to be deleted when the target gene-to-reference gene ratio was $\leq 0.5$.

\section{Statistical analysis}

Categorical variables were described using frequency distributions, and continuous variables were stated using medians and ranges. Correlations between genes was evaluated using the Spearman's $\rho$ correlation. Association between categorical variables was assessed with the $\chi^{2}$ test (or Fisher's exact test when appropriate). Differences were considered statistically significant when 
Table 2 Primer sequences and qPCR conditions used to quantify MED1, STARD3, HER2, GRB7, THRA, RARA, TOP2A, IGFBP4, CCR7, KRT20, KRT19, GAS, ACBT, GAPDH and SSTR2 ${ }^{\mathrm{a}}$

\begin{tabular}{|c|c|c|c|c|c|c|}
\hline $\begin{array}{l}\text { GenBank accession } \\
\text { number }\end{array}$ & Gene name/primer & Sequence $5^{\prime}-3^{\prime}$ & $\begin{array}{c}\text { Size } \\
\text { nt }\end{array}$ & $\mathrm{GC}, \%$ & $\begin{array}{l}\text { Amplicon, } \\
\text { bp }\end{array}$ & $\begin{array}{c}\text { Annealing } \\
\text { temperature }\end{array}$ \\
\hline \multirow[t]{2}{*}{ NP_004765 } & MED1 sense & ATT CTC CTG GGC TTC TCC AA & 20 & $50 \%$ & 97 & $54^{\circ} \mathrm{C}$ \\
\hline & MED1 antisense & CCA CAC ACC AGG GAG TCA TT & 20 & $55 \%$ & & \\
\hline \multirow[t]{2}{*}{ NP_006795 } & STARD3 sense & CAG GCT GCT AGG GTG TAA CTG & 21 & $57 \%$ & 114 & $64^{\circ} \mathrm{C}$ \\
\hline & STARD3 antisense & GAC AGA GCA CCG GAG AAC AG & 20 & $60 \%$ & & \\
\hline \multirow[t]{2}{*}{ NM_004448 } & HER2 sense & GCT CCC CAT ATG TCT CCC G & 19 & $63 \%$ & 101 & $58^{\circ} \mathrm{C}$ \\
\hline & HER2 antisense & CCG GAC ATG GTC TAA GAG GC & 20 & $60 \%$ & & \\
\hline \multirow[t]{2}{*}{ NP_005301 } & GRB7 sense & CTC TGG CTC AGA ACT TCC TGA AT & 23 & $48 \%$ & 142 & $60^{\circ} \mathrm{C}$ \\
\hline & GRB7 antisense & GTG CCC TTG GTG GAG TAA TAG AG & 23 & $52 \%$ & & \\
\hline \multirow[t]{2}{*}{ NP_003241 } & THRA sense & GTG GAC AAG ATC GAG AAG AGT CAG & 24 & $50 \%$ & 119 & $60^{\circ} \mathrm{C}$ \\
\hline & THRA antisense & AGG TCA GTC ACC TTC ATC AGC AG & 23 & $52 \%$ & & \\
\hline \multirow[t]{2}{*}{ NP_000955 } & RARA sense & GGA GTG CTC AGA GTG GGT TC & 20 & $60 \%$ & 110 & $64^{\circ} \mathrm{C}$ \\
\hline & RARA antisense & AGA AGG TCA TGG TGT CCT GCT C & 22 & $55 \%$ & & \\
\hline \multirow[t]{2}{*}{ NP_001058 } & TOP2A sense & GAT TCT GGA CCA ACC TTC AAC TA & 23 & $43 \%$ & 121 & $58^{\circ} \mathrm{C}$ \\
\hline & TOP2A antisense & ATG TAC CAT CCT ACT ATC AAC TCA CTT T & 28 & $36 \%$ & & \\
\hline \multirow[t]{2}{*}{ NP_001543 } & IGFBP4 sense & СTC TTC CGG TGC TGA CCT CT & 20 & $60 \%$ & 146 & $60^{\circ} \mathrm{C}$ \\
\hline & IGFBP4 antisense & GGT GCT CCG GTC TCG AAT & 18 & $61 \%$ & & \\
\hline \multirow[t]{2}{*}{ NP_001829 } & CCR7 sense & AGG CTA AAT CCC AGC CAG AG & 20 & $55 \%$ & 127 & $58^{\circ} \mathrm{C}$ \\
\hline & CCR7 antisense & CTG TGG TGT TGT CTC CGA TG & 20 & $55 \%$ & & \\
\hline \multirow[t]{2}{*}{ XP_352920 } & KRT20 sense & ATG GCT TCA GAA GGA CCA GTT & 21 & $48 \%$ & 95 & $56^{\circ} \mathrm{C}$ \\
\hline & KRT20 antisense & TGG AGA TCA GCT TCC ACT GTT A & 22 & $45 \%$ & & \\
\hline \multirow[t]{2}{*}{ NP_002267 } & KRT19 sense & TGA CAT GCG AAG CCA ATA TG & 20 & $45 \%$ & 124 & $56^{\circ} \mathrm{C}$ \\
\hline & KRT19 antisense & AAA GCC CTC CCC TTC CTA AC & 20 & $55 \%$ & & \\
\hline \multirow[t]{2}{*}{ X00183 } & GAS sense & TCT CCC CAG ACT GGC TCT GA & 20 & $60 \%$ & 146 & $64^{\circ} \mathrm{C}$ \\
\hline & GAS antisense & GCC GAA GTC CAT CCA TCC AT & 20 & $55 \%$ & & \\
\hline \multirow[t]{2}{*}{ NP_001041 } & SSTR2 sense & GCC TCC AGG GTC CAT TAA GG & 20 & $60 \%$ & 101 & $60^{\circ} \mathrm{C}$ \\
\hline & SSTR2 antisense & ATT GAG TGG CTC ATC CGC C & 19 & $58 \%$ & & \\
\hline \multirow[t]{2}{*}{ NP_001092 } & $A C B T$ sense & CCA CAC TGT GCC CAT CTA CG & 20 & $60 \%$ & 99 & $65^{\circ} \mathrm{C}$ \\
\hline & $A C B T$ antisense & AGG ATC TTC ATG AGG TAG TCA GTC AG & 26 & $46 \%$ & & \\
\hline \multirow[t]{2}{*}{ NT_009759 } & GAPDH sense & CTC ACG TAT TCC CCC AGG TT & 20 & $55 \%$ & 161 & $58^{\circ} \mathrm{C}$ \\
\hline & GAPDH antisense & CCC AAA GCA CAT TTC TTC CA & 20 & $45 \%$ & & \\
\hline
\end{tabular}

${ }^{a} \mathrm{qPCR}$, quantitative polymerase chain reaction; MED1, mediator complex subunit 1 gene; STARD3, steroidogenic acute regulatory-related lipid transfer (START) domain containing 3 gene; HER2, human epidermal growth factor receptor 2 gene; GRB7, growth factor receptor-bound protein 7 gene; THRA, thyroid hormone receptor $\alpha$ gene; RARA, retinoic acid receptor $\alpha$ gene; TOP2A, topoisomerase ll $\alpha$ gene; IGFBP4, insulin-like growth factor-binding protein 4 gene; CCR7, C-C chemokine receptor type 7 gene; KRT20, cytokeratin 20 gene; KRT19, cytokeratin 19 gene; GAS, gastrin gene; ACBT, $\beta$-actin gene; GAPDH, glyceraldehyde 3phosphate dehydrogenase gene; SSTR2, somatostatin receptor type II gene.

$P<0.05$. Survival rates were estimated from the date of surgery to the date of the event of interest using the Kaplan-Meier method. The median survival was calculated with $95 \%$ confidence interval $(95 \% \mathrm{CI})$. For overall survival (OS), the event of interest was death, regardless of the cause. Patients lost to follow-up were censored at the last documented visit. For relapse-free survival (RFS), the event of interest was recurrence. Patients who were alive at the last follow-up examination and without recurrence were censored at the time of the last followup examination. Patients who died without recurrence were censored at the date of death. Differences in survival rates were compared using a log-rank test. Statistical analyses were performed with Stata 10.0 software (Stata Corp., College Station, TX, USA).

\section{Results}

Description of the study population

Eighty-six patients with HER2-amplified breast cancer were included in the study. The median follow-up period was 55 months (range, 6 to 81 months). A total of 25 patients (29\%) relapsed after a median of 18 months from the date of surgery (range, 2 to 71 months), and 17 patients $(20 \%)$ died after a median of 31 months (range, 6 to 78 months). The 5-year RFS rate was 69\% (95\% CI, $57 \%$ to $78 \%$ ) and the 5 -year OS rate was $79 \%$ ( $95 \% \mathrm{CI}, 67 \%$ to $87 \%$ ). There were no statistical associations between RFS or OS and the adjuvant treatment administered. The distribution of tumors relative to their pattern of amplified and nonamplified genes was homogeneous in the different treatment groups. 
Analysis of the Chr17q12-q21 amplicon by qPCR

The variability in the efficiency of each parameter was between $92 \%$ and $105 \%$ with a standard deviation of 0.04. The reference genes (SSTR2, GAPDH and ACBT) were chosen in regions previously described as presenting a low level of instability or amplification $[25,26]$ and were controlled together to detect amplification. Their crossing point values were $19.2 \pm 0.56,18.7 \pm 0.47$ and $17.6 \pm 0.43$, respectively. The absence of SSTR 2 amplification was confirmed in all samples by measuring the SSTR2:GAPDH and SSTR2:ACBT ratios, which in all cases were $<1.5$. Finally, none of the 40 HER2-negative cancer specimens (negative controls) showed amplification of the studied genes. The status (amplified, deleted or normal) of the 11 genes (MED1, STARD3, GRB7, THRA, RARA, TOP2A, IGFBP4, CCR7, KRT20, KRT19 and $G A S$ ) evaluated in the 86 HER2-positive cancer samples is summarized in Table 3. Coamplification with HER2 occurred in $65.1 \%$ of samples for MED1 (56 of 86), 93\% for STARD3 (80 of 86), 97.7\% for GRB7 (84 of 86), $54.7 \%$ for THRA ( 47 of 86 ), $26.7 \%$ for RARA (23 of 86), $26.7 \%$ for TOP $2 A$ (23 of 86 ), $20.9 \%$ for IGFBP4 (18 of 86 ), $20.9 \%$ for CCR7 (18 of 86), $14 \%$ for KRT20 (12 of 86$), 11.6 \%$ for KRT19 (10 of 86 ) and $7 \%$ for GAS (6 of 86). HER2 presented the highest level of amplification (mean, 6.4; range, 2 to 32), whereas the frequency of amplification of the other genes decreased according to the distance of the gene from HER2 (Figure 1). The amplification levels of HER 2 and of the other genes were compared by linear regression analysis. HER2 amplification levels were correlated only with the amplification levels of MED1 ( $\rho=0.84)$, STARD3 $(\rho=0.87)$ and GRB7 $(\rho=0.93)$, but not of other genes, particularly TOP2A $(\rho=0.65)$. Gene deletions occurred in fewer than $5.8 \%$ of the samples, regardless of the gene studied (Table 3).

\section{Relation between the pattern of gene amplification and clinical characteristics}

Node status (N), Scarff-Bloom-Richardson histological (SBR) grade and ER/PR-negative status were significantly associated with worse outcomes in terms of both RFS rate $(P=0.007, P=0.004$ and $P=0.024$, respectively) and OS rate $(P=0.020, P=0.048$ and $P=0.076$, respectively) (univariate analysis) (see Table 4 and Figure 2 for ER/PR status). The patterns of gene amplification were not significantly correlated with the $\mathrm{T}$ or SBR grade. Conversely, MED1 amplification tended to be associated with ER-positive tumors $(P=0.072)$, whereas amplification of RARA, KRT20 or KRT19 was significantly associated with node-positive breast cancers $(P=0.030, P=0.002$ and $P=0.033$, respectively). Moreover, patients with TOP2A-amplified tumors tended to have better RFS rates (hazard ratio $(\mathrm{HR})=0.47,95 \% \mathrm{CI}$
Table 3 Gene amplification quantification relative to the SSTR2 reference gene ${ }^{a}$

\begin{tabular}{|c|c|c|}
\hline Gene & $\begin{array}{l}\text { Number of patients (\%) } \\
(n=86)\end{array}$ & Median (range) \\
\hline \multicolumn{3}{|l|}{$\overline{M E D 1}$} \\
\hline Deletion & $3(3.5 \%)$ & 0.5 (0.5 to 0.5$)$ \\
\hline Normal & 27 (31.4\%) & 0.9 (0.6 to 1.9$)$ \\
\hline Amplification & $56(65.1 \%)$ & 4.6 (2 to 27.8$)$ \\
\hline Total & 86 (100.0\%) & 2.6 (0.5 to 27.8$)$ \\
\hline \multicolumn{3}{|l|}{ STARD3 } \\
\hline Deletion & 0 & - \\
\hline Normal & $6(7.0 \%)$ & 1.5 (0.7 to 1.9$)$ \\
\hline Amplification & 80 (93.0\%) & 6.4 (2.0 to 74.9$)$ \\
\hline Total & 86 (100.0\%) & 5.9 (0.7 to 74.9$)$ \\
\hline \multicolumn{3}{|l|}{ HER2 } \\
\hline Amplification & $86(100.0 \%)$ & 6.4 (2 to 32 ) \\
\hline \multicolumn{3}{|l|}{ GRB7 } \\
\hline Deletion & 0 & - \\
\hline Normal & $2(2.3 \%)$ & 1.1 (0.6 to 1.7$)$ \\
\hline Amplification & 84 (97.7\%) & 6.8 (2.3 to 36.5$)$ \\
\hline Total & $86(100.0 \%)$ & 6.6 (0.6 to 36.5 ) \\
\hline \multicolumn{3}{|l|}{ THRA } \\
\hline Deletion & $1(1.2 \%)$ & 0.5 \\
\hline Normal & $38(44.2 \%)$ & 1.1 (0.6 to 1.9$)$ \\
\hline Amplification & 47 (54.7\%) & 4.4 (2.0 to 11.7$)$ \\
\hline Total & 86 (100.0\%) & $2.2(0.5$ to 11.7$)$ \\
\hline \multicolumn{3}{|l|}{ RARA } \\
\hline Deletion & $3(3.5 \%)$ & 0.5 (0.4 to 0.5$)$ \\
\hline Normal & 60 (69.8\%) & $1.0(0.6$ to 1.9$)$ \\
\hline Amplification & $23(26.7 \%)$ & 3.4 (2.0 to 11.1$)$ \\
\hline Total & $86(100.0 \%)$ & 1.1 (0.4 to 11.1$)$ \\
\hline \multicolumn{3}{|l|}{ TOP2A } \\
\hline Deletion & $4(4.7 \%)$ & 0.5 (0.5 to 0.5$)$ \\
\hline Normal & 59 (68.6\%) & 1.0 (0.6 to 1.8$)$ \\
\hline Amplification & $23(26.7 \%)$ & $3.2(2$ to 7$)$ \\
\hline Total & 86 (100.0\%) & $1.1(0.5$ to 7$)$ \\
\hline \multicolumn{3}{|l|}{ IGFBP4 } \\
\hline Deletion & $5(5.8 \%)$ & 0.5 (0.5 to 0.5$)$ \\
\hline Normal & $63(73.3 \%)$ & 1.0 (0.6 to 1.9$)$ \\
\hline Amplification & 18 (20.9\%) & 3.1 (2 to 8 ) \\
\hline Total & 86 (100.0\%) & 1.1 (0.5 to 8 ) \\
\hline \multicolumn{3}{|l|}{ CCR7 } \\
\hline Deletion & $3(3.5 \%)$ & $0.4(0.4$ to 0.5$)$ \\
\hline Normal & $65(75.6 \%)$ & 0.9 (0.6 to 1.8$)$ \\
\hline Amplification & 18 (20.9\%) & 3.3 (2 to 14.9$)$ \\
\hline Total & $86(100.0 \%)$ & 1.0 (0.4 to 14.9$)$ \\
\hline \multicolumn{3}{|l|}{ KRT20 } \\
\hline Deletion & $2(2.3 \%)$ & 0.5 (0.5 to 0.5$)$ \\
\hline Normal & 72 (83.7\%) & 1.1 (0.6 to 1.8 ) \\
\hline Amplification & $12(14.0 \%)$ & 3.1 (2.3 to 11.6$)$ \\
\hline Total & 86 (100.0\%) & 1.1 (0.5 to 11.6$)$ \\
\hline \multicolumn{3}{|l|}{ KRT19 } \\
\hline Deletion & $5(5.8 \%)$ & 0.5 (0.5 to 0.5 ) \\
\hline Normal & 71 (82.6\%) & 1.0 (0.6 to 1.8 ) \\
\hline
\end{tabular}


Table 3 Gene amplification quantification relative to the SSTR2 reference gene ${ }^{a}$ (Continued)

\begin{tabular}{lcc}
\hline Amplification & $10(11.6 \%)$ & $3.0(2$ to 6.4$)$ \\
Total & $86(100.0 \%)$ & $1.0(0.5$ to 6.4$)$ \\
GAS & $2(2.3 \%)$ & $0.5(0.4$ to 0.5$)$ \\
Deletion & $78(90.7 \%)$ & $1.0(0.6$ to 1.7$)$ \\
Normal & $6(7.0 \%)$ & $2.8(2$ to 14.4$)$ \\
Amplification & $86(100.0 \%)$ & $1.0(0.4$ to 14.4$)$ \\
Total &
\end{tabular}

${ }^{a}$ Amplification: target gene/SSTR2 ratio $\geq 2$; deletion: target gene/SSTR2 ratio $\leq 0.5$; normal: $0.5<$ target gene/SSTR2 ratio $<2$. MED1, mediator complex subunit 1 gene; STARD3, steroidogenic acute regulatory-related lipid transfer (START) domain containing 3 gene; HER2, human epidermal growth factor receptor 2 gene; GRB7, growth factor receptor-bound protein 7 gene; THRA, thyroid hormone receptor $\alpha$ gene; RARA, retinoic acid receptor $\alpha$ gene; TOP $2 A$, topoisomerase ll $\alpha$ gene; IGFBP4, insulin-like growth factor-binding protein 4 gene; CCR7, C-C chemokine receptor type 7 gene; KRT20, cytokeratin 20 gene; KRT19, cytokeratin 19 gene; GAS, gastrin gene; SSTR2, somatostatin receptor type II gene.
0.16 to $1.38, P=0.159)$ and $\mathrm{OS}$ rates $(\mathrm{HR}=0.34,95 \%$ CI 0.08 to $1.48, P=0.132$ ) than patients with TOP2A nonamplified tumors (Figure 2). The subgroup of patients with ER/PR-negative cancers without amplification of TOP $2 A$ in particular had the worst RFS rates $(\mathrm{HR}=0.29,95 \% \mathrm{CI} 0.13$ to $0.65, P=0.001)$ and the worst OS rates $(\mathrm{HR}=0.28,95 \%$ CI 0.10 to 0.76 , $P=0.008)$.

\section{Discussion}

In this work, we quantified gene amplification in the $17 \mathrm{q} 12$ to $17 \mathrm{q} 21$ region around HER2 in HER2-amplified breast tumors. Among the patients with primary breast cancer, fewer than $12 \%$ had HER2-positive tumors. This result is in accordance with recent studies reporting $12 \%$ to $15 \%$ of HER 2 amplification compared to the $20 \%$ to $25 \%$ found in historical studies [29,30], in which Chr17

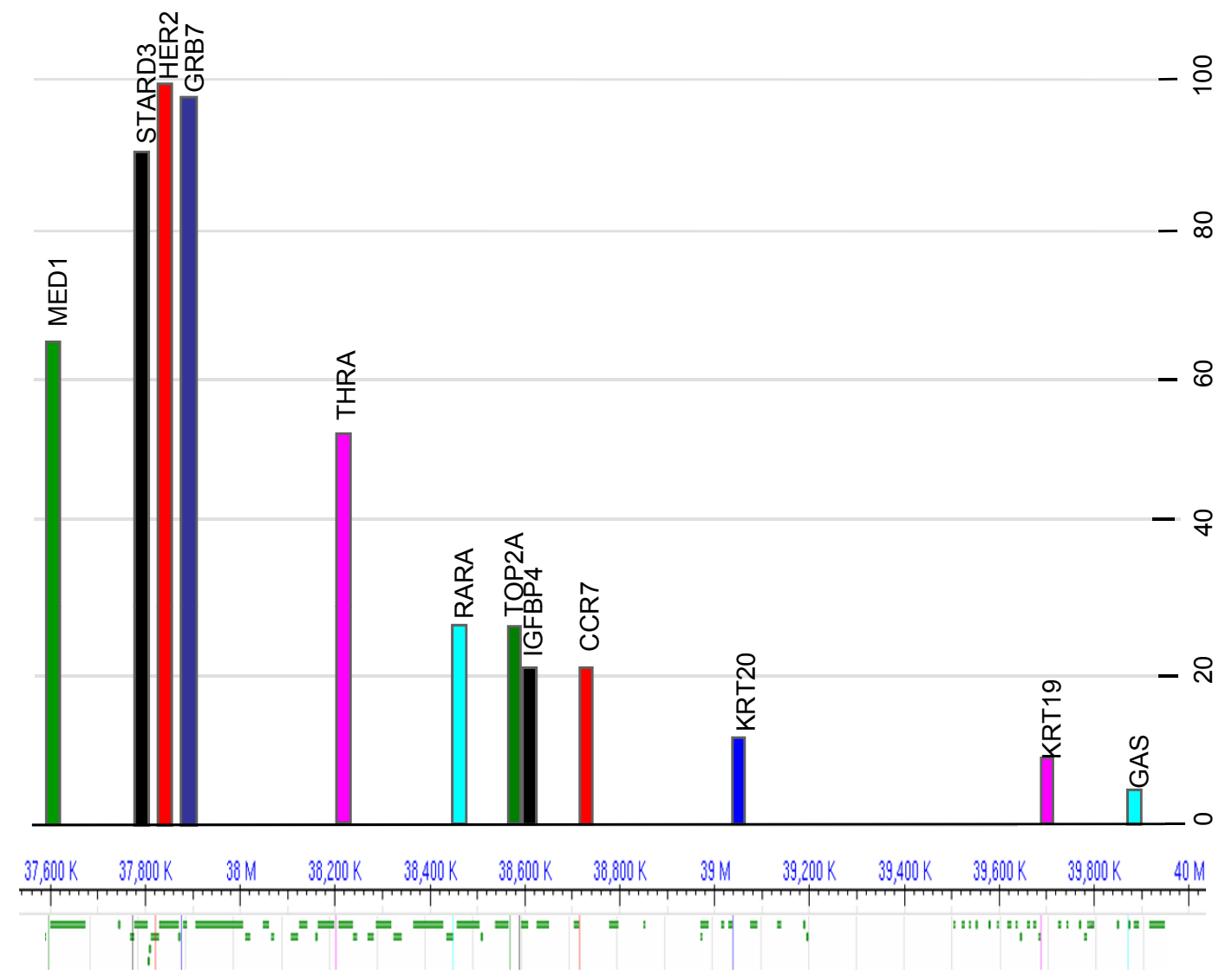

Figure 1 Gene amplification distribution on chromosome 17q12-q21 in Human epidermal growth factor receptor 2 (HER2)-positive breast cancer specimens on the basis of the overview of chromosome 17 with the National Center for Biotechnology Information's Sequence Viewer version $\mathbf{2 . 9}$ database [55]. The frequency of amplification (percentage of positive breast cancer specimens on the $y$-axis) for a gene decreases with the increase of its distance from HER2. MED1, mediator complex subunit 1 gene; STARD3, steroidogenic acute regulatoryrelated lipid transfer (START) domain containing 3 gene; HER2, human epidermal growth factor receptor 2 gene; GRB7, growth factor receptorbound protein 7 gene; THRA, thyroid hormone receptor $\alpha$ gene; RARA, retinoic acid receptor $\alpha$ gene; TOP2A, topoisomerase II $\alpha$ gene; IGFBP4, insulin-like growth factor-binding protein 4 gene; CCR7, C-C chemokine receptor type 7 gene; KRT20, cytokeratin 20 gene; KRT19, cytokeratin 19 gene; GAS, gastrin gene. 


\begin{tabular}{|c|c|c|c|c|c|c|c|}
\hline \multirow[b]{2}{*}{ Variable } & \multirow[b]{2}{*}{ Number of patients } & \multicolumn{3}{|c|}{ RFS } & \multicolumn{3}{|c|}{ OS } \\
\hline & & Events & 5-year RFS & HR (95\% Cl) & Events & 5-year OS & HR (95\% CI) \\
\hline \multicolumn{8}{|l|}{$T$} \\
\hline 1 & 35 & 8 & 74.2 & 1 & 6 & 84.2 & 1 \\
\hline 2 & 46 & 15 & 65.9 & 1.51 (0.64 to 3.58) & 10 & 74.3 & 1.30 (0.47 to 3.60$)$ \\
\hline \multirow[t]{2}{*}{3 or 4} & 5 & 2 & 53.3 & 2.15 (0.45 to 10.4$)$ & 1 & 80.0 & 1.34 (0.16 to 11.3$)$ \\
\hline & & \multicolumn{3}{|c|}{$P=0.510^{*}$} & \multicolumn{3}{|c|}{$P=0.868^{*}$} \\
\hline \multicolumn{8}{|l|}{ N } \\
\hline $\mathrm{N}^{-}$ & 35 & 4 & 88.1 & 1 & 2 & 94.2 & 1 \\
\hline \multirow[t]{2}{*}{$\mathrm{N}^{+}$} & 51 & 21 & 55.8 & 3.94 (1.35 to 11.5$)$ & 15 & 70.0 & 4.89 (1.12 to 21.4$)$ \\
\hline & & \multicolumn{3}{|c|}{$P=0.007^{*}$} & \multicolumn{3}{|c|}{$P=0.020^{*}$} \\
\hline \multicolumn{8}{|l|}{ SBR } \\
\hline 2 & 36 & 5 & 84.9 & 1 & 4 & 89.4 & 1 \\
\hline \multirow[t]{2}{*}{3} & 49 & 20 & 55.8 & 3.80 (1.42 to 10.2$)$ & 13 & 70.8 & 2.96 (0.96 to 9.15$)$ \\
\hline & & \multicolumn{3}{|c|}{$P=0.004^{*}$} & \multicolumn{3}{|c|}{$P=0.048^{*}$} \\
\hline \multicolumn{8}{|l|}{ ER } \\
\hline $\mathrm{ER}^{-}$ & 60 & 19 & 66.9 & 1 & 13 & 76.2 & 1 \\
\hline \multirow[t]{2}{*}{$\mathrm{ER}^{+}$} & 26 & 6 & 70.1 & $0.64(0.25$ to 1.60$)$ & 4 & 84.9 & 0.68 (0.22 to 2.10$)$ \\
\hline & & \multicolumn{3}{|c|}{$P=0.333^{*}$} & \multicolumn{3}{|c|}{$P=0.505^{*}$} \\
\hline PR & & & & & & & \\
\hline $\mathrm{PR}^{-}$ & 44 & 18 & 57.6 & 1 & 13 & 67.3 & 1 \\
\hline $\mathrm{PR}^{+}$ & 42 & 7 & 80.9 & 0.36 (0.15 to 0.87$)$ & 4 & 92.4 & 0.32 (0.10 to 0.99$)$ \\
\hline & & & $P=0.018^{*}$ & & & $P=0 . C$ & $37^{*}$ \\
\hline$E R / P R$ & & & & & & & \\
\hline $\mathrm{ER}^{-} / \mathrm{PR}^{-}$ & 42 & 17 & 58.7 & 1 & 12 & 68.9 & 1 \\
\hline Other & 44 & 8 & 78.2 & 0.39 (0.17 to 0.91$)$ & 5 & 89.2 & $0.40(0.14$ to 1.14$)$ \\
\hline & & & $P=0.024^{*}$ & & & $P=0 . C$ & $76^{*}$ \\
\hline MED1 & & & & & & & \\
\hline Del/Nm & 30 & 10 & 66.2 & 1 & 7 & 72.9 & 1 \\
\hline Amp & 56 & 15 & 70.0 & 0.76 (0.34 to 1.70$)$ & 10 & 82.5 & 0.63 (0.23 to 1.69$)$ \\
\hline & & & $P=0.507^{*}$ & & & $P=0.3$ & $54^{*}$ \\
\hline STARD3 & & & & & & & \\
\hline $\mathrm{Del} / \mathrm{Nm}$ & 6 & 2 & 55.6 & 1 & 2 & 53.3 & 1 \\
\hline Amp & 80 & 23 & 69.4 & 0.85 (0.20 to 3.62$)$ & 15 & 80.9 & 0.48 (0.11 to 2.14$)$ \\
\hline & & & $P=0.826^{*}$ & & & $P=0.3$ & $27^{*}$ \\
\hline GRB7 & & & & & & & \\
\hline $\mathrm{Del} / \mathrm{Nm}$ & 2 & 1 & 50.0 & 1 & 1 & 0.00 & 1 \\
\hline Amp & 84 & 24 & 69.3 & 0.30 (0.04 to 2.33 ) & 16 & 80.1 & 0.15 (0.02 to 1.20$)$ \\
\hline & & & $P=0.225^{*}$ & & & $P=0 . C$ & $38^{*}$ \\
\hline THRA & & & & & & & \\
\hline $\mathrm{Del} / \mathrm{Nm}$ & 39 & 16 & 59.0 & 1 & 11 & 73.8 & 1 \\
\hline Amp & 47 & 9 & 79.3 & $0.50(0.22$ to 1.13$)$ & 6 & 84.7 & 0.53 (0.19 to 1.43$)$ \\
\hline & & & $P=0.090^{*}$ & & & $P=0.1$ & $99^{*}$ \\
\hline RARA & & & & & & & \\
\hline Del/Nm & 63 & 21 & 64.1 & 1 & 15 & 75.2 & 1 \\
\hline Amp & 23 & 4 & 82.4 & $0.50(0.17$ to 1.45$)$ & 2 & 91.3 & 0.36 (0.08 to 1.59$)$ \\
\hline & & & $P=0.190^{*}$ & & & $P=0.1$ & $62^{*}$ \\
\hline TOP2A & & & & & & & \\
\hline Del/Nm & 63 & 21 & 63.7 & 1 & 15 & 74.8 & 1 \\
\hline Amp & 23 & 4 & 82.4 & 0.47 (0.16 to 1.38$)$ & 2 & 91.3 & 0.34 (0.08 to 1.48$)$ \\
\hline & & & $P=0.159^{*}$ & & & $P=0.1$ & $32^{*}$ \\
\hline
\end{tabular}


Table 4 Univariate analysis of the different variables ${ }^{a}$ (Continued)

\begin{tabular}{|c|c|c|c|c|c|c|c|}
\hline \multicolumn{8}{|l|}{ IGFBP4 } \\
\hline $\mathrm{Del} / \mathrm{Nm}$ & 68 & 21 & 66.6 & 1 & 15 & 76.9 & 1 \\
\hline \multirow[t]{2}{*}{ Amp } & 18 & 4 & 77.4 & 0.70 (0.24 to 2.06) & 2 & 88.9 & 0.49 (0.11 to 2.16) \\
\hline & & \multicolumn{3}{|c|}{$P=0.520^{*}$} & \multicolumn{3}{|c|}{$P=0.335^{*}$} \\
\hline \multicolumn{8}{|l|}{ CCR7 } \\
\hline $\mathrm{Del} / \mathrm{Nm}$ & 68 & 21 & 67.0 & 1 & 16 & 75.3 & 1 \\
\hline \multirow[t]{2}{*}{ Amp } & 18 & 4 & 75.4 & $0.66(0.22$ to 1.93$)$ & 1 & 94.4 & 0.21 (0.03 to 1.61 ) \\
\hline & & \multicolumn{3}{|c|}{$P=0.442^{*}$} & \multicolumn{3}{|c|}{$P=0.099^{*}$} \\
\hline \multicolumn{8}{|l|}{ KRT2O } \\
\hline $\mathrm{Del} / \mathrm{Nm}$ & 74 & 21 & 69.2 & 1 & 15 & 78.8 & 1 \\
\hline \multirow[t]{2}{*}{ Amp } & 12 & 4 & 66.7 & 1.31 (0.45 to 3.81$)$ & 2 & 81.5 & 1.02 (0.23 to 4.49$)$ \\
\hline & & \multicolumn{3}{|c|}{$P=0.622^{*}$} & \multicolumn{3}{|c|}{$P=0.981^{*}$} \\
\hline \multicolumn{8}{|l|}{ KRT19 } \\
\hline $\mathrm{Del} / \mathrm{Nm}$ & 76 & 23 & 67.6 & 1 & 16 & 78.3 & 1 \\
\hline \multirow[t]{2}{*}{ Amp } & 10 & 2 & 78.7 & 0.70 (0.16 to 2.96$)$ & 1 & 90.0 & 0.64 (0.08 to 4.82 ) \\
\hline & & \multicolumn{3}{|c|}{$P=0.624^{*}$} & \multicolumn{3}{|c|}{$P=0.658^{*}$} \\
\hline \multicolumn{8}{|l|}{ GAS } \\
\hline $\mathrm{Del} / \mathrm{Nm}$ & 80 & 24 & 68.0 & 1 & 16 & 79.1 & 1 \\
\hline \multirow[t]{2}{*}{ Amp } & 6 & 1 & 83.3 & 0.64 (0.09 to 4.74$)$ & 1 & 83.3 & 1.21 (0.16 to 9.20$)$ \\
\hline & & \multicolumn{3}{|c|}{$P=0.660^{*}$} & \multicolumn{3}{|c|}{$P=0.852^{*}$} \\
\hline $\begin{array}{l}\mathrm{ER} / \mathrm{PR}^{-} \text {and TOP2A } \\
\mathrm{Del} / \mathrm{Nm}\end{array}$ & 30 & 15 & 49.2 & 1 & 11 & 61.0 & 1 \\
\hline \multirow[t]{2}{*}{ Others } & 56 & 10 & 79.2 & 0.29 (0.13 to 0.65$)$ & 6 & 89.7 & 0.28 (0.10 to 0.76$)$ \\
\hline & & \multicolumn{3}{|c|}{$P=0.001^{*}$} & \multicolumn{3}{|c|}{$P=0.008^{*}$} \\
\hline
\end{tabular}

${ }^{\mathrm{a}} \mathrm{T}$, tumor size; N, lymph node status; SBR grade, Scarff-Bloom-Richardson histological grade; ER, estrogen receptor; PR, progesterone receptor; Del, deletion; Nm, normal; Amp, amplification; RFS, relapse-free survival; OS, overall survival; HR, hazard ratio; $95 \% \mathrm{Cl}, 95 \%$ confidence interval; MED1, mediator complex subunit 1 gene; STARD3, steroidogenic acute regulatory-related lipid transfer (START) domain containing 3 gene; HER2, human epidermal growth factor receptor 2 gene; GRB7, growth factor receptor-bound protein 7 gene; THRA, thyroid hormone receptor $\alpha$ gene; RARA, retinoic acid receptor $\alpha$ gene; TOP2A, topoisomerase Il $\alpha$ gene; IGFBP4, insulin-like growth factor-binding protein 4 gene; CCR7, C-C chemokine receptor type 7 gene; KRT20, cytokeratin 20 gene; KRT19, cytokeratin 19 gene; GAS, gastrin gene; SSTR2, somatostatin receptor type II gene; *log-rank test.

polysomy may have led to discordant interpretations between higher signals due to polysomy and those due to an absolute increase of HER2 gene copy number in a significant proportion of cases [31]. Gene amplification on the centromeric side (MED1 and STARD3) and the distal side (GRB7, THRA, RARA, TOP2A, IGFBP4, CCR7, $K R T 20, K R T 19$ and GAS) relative to HER2 localization on Chr17q was determined by qPCR, an efficient method for performing copy number analysis [32], and with reference genes located on Chr17 (SSTR2) and Chr4 and Chr2 (GAPDH and $A C B T$, respectively) to differentiate polysomy from true amplification. In fact, tumors presenting only Chr17 polysomy should not be considered as HER2amplified, and patients with this presentation might not benefit from anti-HER2 therapy, although these tumors present moderate HER2 overexpression [28,33], but only as a result of treatment with anthracyclines [34].

We have confirmed that gene amplification, including that of TOP $2 A$, occurs only in patients with HER2amplified breast tumors. We then showed that HER2 presents the highest amplification value and that the frequency of amplification of a gene decreases with its distance from HER2. These results suggest that instability within Chr17q is driven by HER2 amplification. Indeed, HER2-positive tumors have higher levels of overall genomic instability than HER2-negative tumors, supporting the idea that HER2 amplification is the key amplicon driver on Chr17q [35,36]. Moreover, we found a correlation between the amplification levels of HER2 and that of $M E D 1$, STARD3 and GRB7, but not of $T O P 2 A$ and the other genes localized on the distal side of Chr17q. Therefore, the SRA of HER2 seems to be limited to a small number of genes, among which are STARD3 and GRB7 as described by Katoh et al. [37] and as recently reported by Beroukhim et al. [38] in different cancer types. Kuwahara et al. [39] identified a region between HER2 and GRB7 (a gene located $47 \mathrm{~kb}$ from HER2) that contains a recombinant hot spot for amplification, deletion and translocation. This site might be located between GRB7 and THRA, a gene located $315 \mathrm{~kb}$ from GRB7, given that 84 (97.7\%) of the cancer specimens we assessed presented GRB7 amplification, whereas only 47 (54.7\%) showed THRA amplification. The presence of this hot spot might explain why the 


\section{RFS}

A

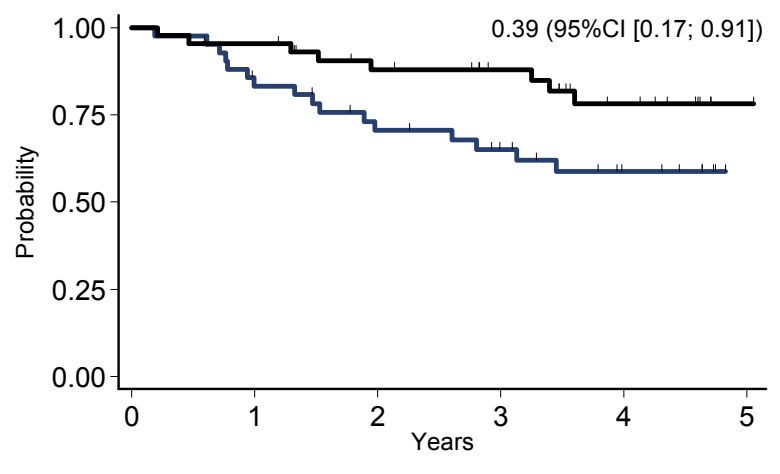

ER-/PR- — Other —

B

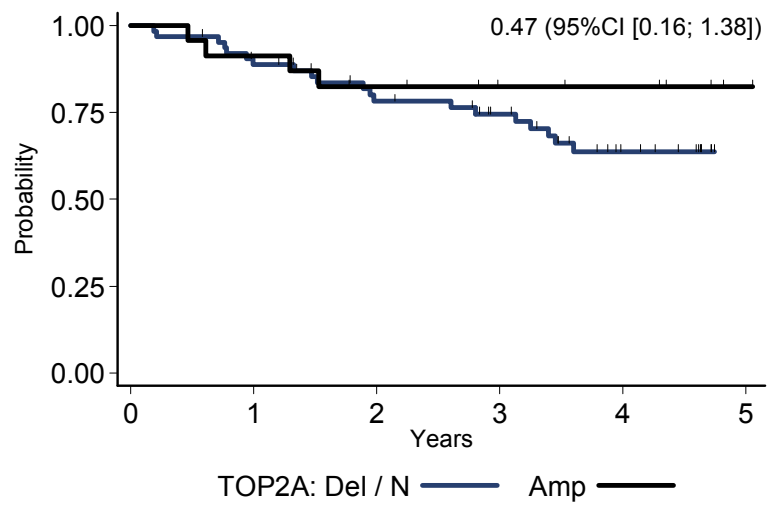

C

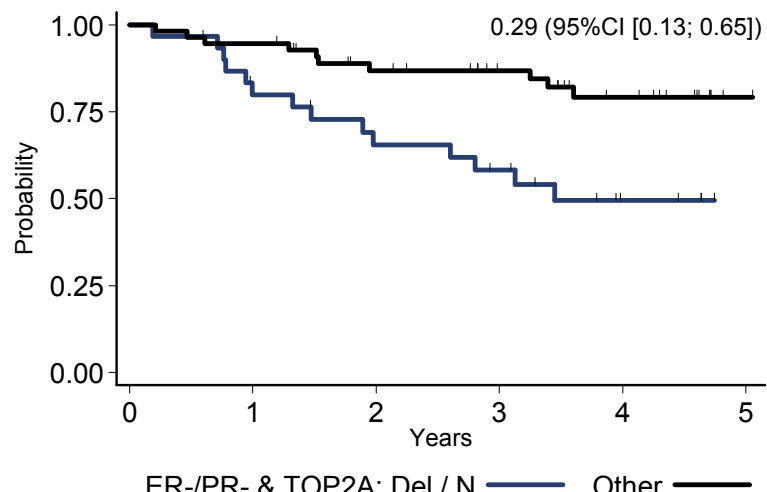

OS



ER-/PR- — Other $\longrightarrow$
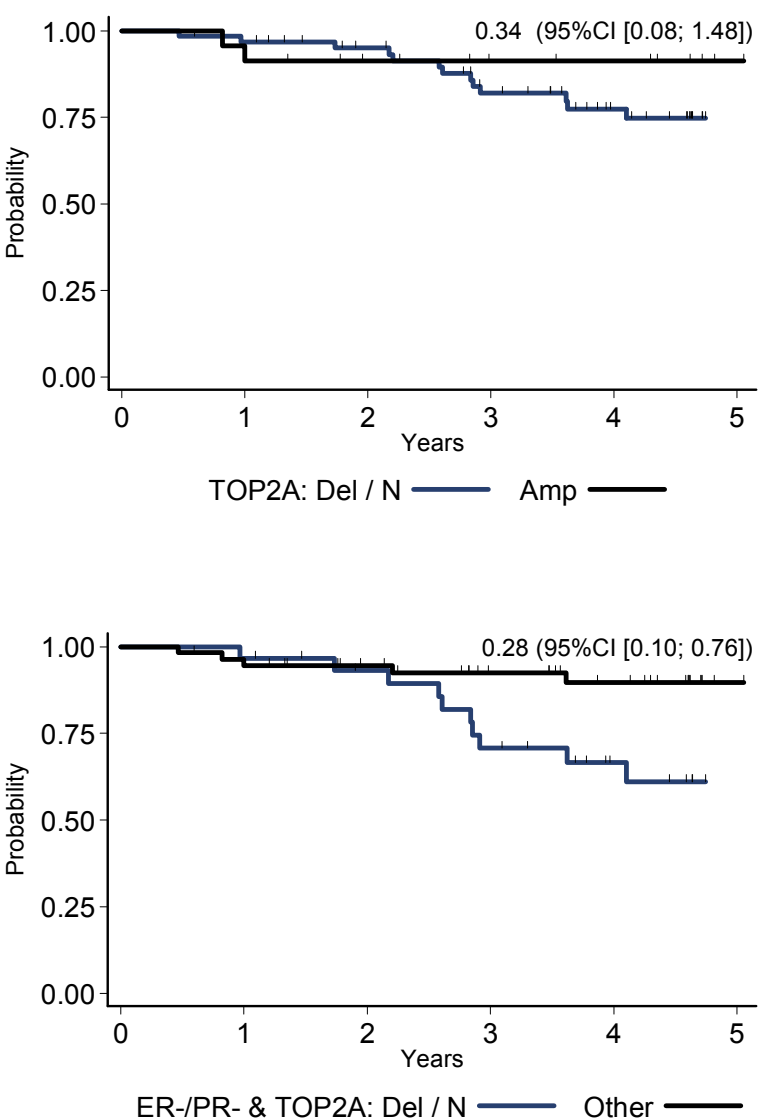

Figure 2 Kaplan-Meier curves for relapse-free survival (RFS) and overall survival (OS). (a) Estrogen receptor/progesterone receptor (ER/PR) status. Blue line indicates ER- and PR-negative (ER/PR-) status; black line indicates ER-, $\mathrm{PR}$ - or ER/PR-positive (ER/PR+ $\mathrm{ER}^{+} / \mathrm{PR}^{-}$or $\left.E R^{+} / \mathrm{PR}^{+}\right) \mathrm{Status}^{-}$ (b) Topoisomerase $\| \alpha(T O P 2 A)$ amplification. Blue line indicates deleted or nonamplified (normal) TOP2A (TOP2A Del/N); black line indicates amplified TOP2A (TOP2A Amp). For RFS, $P=0.159$; for OS, $P=0.132$. (c) TOP2A and ER/PR status. Blue line indicates ER- and PR-negative (ER/PR') and deleted or nonamplified TOP2A (TOP2A Del/N); black line indicates ER-, PR-, or ER/PR-positive (ER'/PR ${ }^{+}, \mathrm{ER}^{+} / \mathrm{PR}^{-}$and $\mathrm{ER}^{+} / \mathrm{PR}^{+}$) status and amplified TOP2A (TOP2A Amp). For RFS, $P=0.001$; for OS, $P=0.008$. 
frequency of recombination for a gene is higher when it is located closer to HER2 and gradually decreases for genes located far away from HER2. In general, the gene amplification architectures derived from our results illustrate the complexity of the rearrangement mechanisms (sister chromatid breakage-fusion-bridge cycles, formation and reinsertion of double minutes and repeated units at a single locus) and highlight the diversity of HER2-amplified cancers [40,41].

Finally, we found a low overall number of deletions $(<5.8 \%)$, regardless of the gene analyzed. For TOP $2 A$, the deletion rate was $4.7 \%$, which is low compared with values found in other studies (between $8.1 \%$ and 35\%) [22]. This might be explained by the fact that in heterogenic tumors, which simultaneously present amplifications and deletions, qPCR cannot detect deletions that are present in a very small number of cells. It is also possible that in certain studies the percentage of tumors with deletions was overestimated as a result of poor standardization of the FISH technique. Indeed, Di Leo et al. $[42,43]$ recently showed high interlaboratory variations for TOP $2 A$ quantification, whereas Press et al. [44] found a deletion rate comparable to ours in a prospective study using standardized FISH.

We then investigated the clinical impact of Chr17 anomalies. Amplification of RARA, KRT20 and KRT19 correlated with node invasion, suggesting that tumors with amplification of genes on the distal side of Chr17q are more aggressive than tumors with amplifications restricted to the SRA of HER2. MED1 amplification showed a tendency to be associated with ER-positive tumors. MED1 encodes the mediator complex subunit 1 (MED1) [45] that anchors mediator to ER $\beta$ [46] while also interacting with ER $\alpha$ [47]. Although our study did not show any significant impact of $M E D 1$ amplification on survival, the prognostic value of $M E D 1$ should nevertheless be evaluated in a larger ER/PR-positive population. Similarly, TOP $2 A$ amplification was not a statistically significant prognostic factor, but patients with tumors in which TOP $2 A$ was amplified tended to have better RFS and OS rates (see Figure 2b). This result is in accord with a recent study in which patients with HER2-positive, TOP2A-amplified cancers presented a trend of better survival than patients with HER2-positive breast cancers with deleted or normal TOP $2 A$ [48]. Conversely, the subgroup of patients with ER/PR-negative breast cancers and nonamplified (normal or deleted) TOP $2 A$ showed the least favorable RFS and OS rates in our population. We could not determine whether the prognosis was even less favorable in the case of ER/PRnegative tumors with TOP2A-deleted status than of tumors with normal TOP $2 A$. Nevertheless, TOP $2 A$ deletions, which are often heterozygous [49], do not result in total loss of expression of the protein [50]. Their unfavorable prognosis might be explained by the fact that ER/PR-negative, TOP2A nonamplified tumors may not be responsive to hormone therapy and/or to anthracycline-based therapy because of the absence or insufficient number of targets. Adjuvant therapy would thus not be beneficial for these patients. Indeed, recent findings suggest that the presence of TOP $2 A$ deletions is not associated with better chemosensitivity or response to anthracyclines, while the occurrence of TOP $2 A$ amplifications may identify a subgroup of patients with increased response to anthracyclines $[18,44]$. Many studies have been conducted on the impact of the presence of HER2 and TOP $2 A$ amplifications on survival and response to chemotherapy. Only a few studies found that there was no benefit to treating patients with HER2-positive cancer with anthracyclines or that $T O P 2 A$ amplification had no predictive value. The subject remains controversial [51], but nevertheless two large trials (the National Surgical Adjuvant Breast and Bowel Project B-11 and the National Cancer Institute of Canada MA.5 studies) have retrospectively shown a correlation between HER2 amplification and benefit from adjuvant anthracycline-based chemotherapy [52,53]. Moreover, a pooled analysis that included 8 studies and 1,536 HER2-positive patients indicated that anthracyclines were superior to non-anthracycline-based regimens in terms of disease-free and overall survival [54].

\section{Conclusions}

Few studies have used qPCR to assess gene copy number alterations in HER2-amplified breast cancer. The assay we have developed can be used to assess the amplification status of multiple genes. We have shown that MED1, STARD3, TOP2A, GRB7, THRA, RARA, IGFBP4, CCR7, KRT19, KRT20 and GAS amplification occurred only in HER2-amplified breast cancers with variable frequencies. We have confirmed that HER2 seems to drive genomic instability along Chr17q and that TOP2A was not included in the SRA of HER2. The different patterns of amplification we observed suggest complex amplification mechanisms leading to a variety of subtypes. RARA, KRT19 and KRT20 amplification could be related to a more invasive breast cancer profile. Moreover, we confirm the clinical importance of identifying the subgroup of patients with ER/PR-negative, TOP2A nonamplified cancer, as they have the worst prognosis. A prospective study including a larger number of patients treated with trastuzumab and anthracycline-based adjuvant therapy would be useful to determine the predictive value of TOP $2 A$ amplification and the prognostic value of gene copy number variations along Chr17q. 


\section{Abbreviations}

ACBT: $\beta$-actin; CCR7: C-C chemokine receptor type 7; Chr17q: chromosome 17q; ER: estrogen receptor; FISH: fluorescence in situ hybridization; GAPDH: glyceraldehyde 3-phosphate dehydrogenase; GAS: gastrin; GRB7: growth factor receptor-bound protein 7; HER2: human epidermal growth factor receptor 2; IGFBP4: insulin-like growth factor-binding protein 4; KRT19: cytokeratin 19; KRT20: cytokeratin 20; MED1: mediator complex subunit 1; N: nodal status; OS: overall survival; PR: progesterone receptor; $\mathrm{qPCR}$ : quantitative polymerase chain reaction; RARA: retinoic acid receptor a; RFS: relapse-free survival; SBR grade: Scarff-Bloom-Richardson histological grade; SRA: small region of amplification; SSTR2: somatostatin receptor type II; STARD3: steroidogenic acute regulatory-related lipid transfer (START) domain containing 3; THRA: thyroid hormone receptor a; TOP2A: topoisomerase lla; T: tumor size.

\section{Acknowledgements}

This work was funded by the Assistance Publique des Hôpitaux de Marseille (APHM) and the Val d'Aurelle Cancer Center. We thank Philippe Rouanet and Gilles Romieu for clinical samples. We are grateful to E. Andermacher for editing the manuscript.

\section{Author details}

'Laboratoire de Biologie Spécialisée et d'Oncogénétique, Centre Régional de Lutte contre le Cancer Val d'Aurelle-Paul Lamarque, 208, rue des Apothicaires, Montpellier F-34298, France. ${ }^{2}$ Laboratoire de Transfert d'Oncologie Biologie, Assistance Publique, Hôpitaux de Marseille, Boulevard Pierre Dramard, Marseille F-13916, France. ${ }^{3}$ Unité de Biostatistique Centre Régional de Lutte contre le Cancer Val d'Aurelle-Paul Lamarque, 208, rue des Apothicaires, Montpellier F-34298, France. ${ }^{4}$ UMR 911 CRO2: Centre de Recherche en Oncologie biologique et Oncopharmacologie, Boulevard Pierre Dramard, Marseille F-13344, France. ${ }^{5}$ Service d'Oncologie Médicale, Centre Régional de Lutte contre le Cancer Val d'Aurelle-Paul Lamarque, 208, rue des Apothicaires, Montpellier F-34298, France.

\section{Authors' contributions}

PJL contributed to the conception and design of the entire study, coordinated sample collection, interpreted data and drafted the manuscript. FF made the first design of the quantitative polymerase chain reaction (qPCR) assays, contributed to data interpretation as well as statistical analysis and assisted in drafting the manuscript. CMB supervised the statistical analysis and assisted in drafting the manuscript. ACL was responsible for designing and optimizing the qPCR assays and carried out most of the experiments with the DNA samples described in this paper. PMM and LO made original observations leading to this work and contributed to the critical revision of the manuscript. WJ selected the eligible patients, acquired the clinicopathological data and contributed to the drafting of the manuscript. All authors read and approved the final manuscript.

\section{Competing interests}

The authors declare that they have no competing interests.

Received: 28 September 2010 Revised: 19 December 2010

Accepted: 2 February 2011 Published: 2 February 2011

\section{References}

1. Smith I, Procter M, Gelber RD, Guillaume S, Feyereislova A, Dowsett M, Goldhirsch A, Untch M, Mariani G, Baselga J, Kaufmann M, Cameron D, Bell R, Bergh J, Coleman R, Wardley A, Harbeck N, Lopez Rl, Mallmann P, Gelmon K, Wilcken N, Wist E, Sánchez Rovira P, Piccart-Gebhart MJ, HERA study team: 2-year follow-up of trastuzumab after adjuvant chemotherapy in HER2-positive breast cancer: a randomised controlled trial. Lancet 2007, 369:29-36.

2. Joensuu H, Kellokumpu-Lehtinen PL, Bono P, Alanko T, Kataja V, Asola R, Utriainen T, Kokko R, Hemminki A, Tarkkanen M, Turpeenniemi-Hujanen T, Jyrkkiö S, Flander M, Helle L, Ingalsuo S, Johansson K, Jääskeläinen AS, Pajunen M, Rauhala M, Kaleva-Kerola J, Salminen T, Leinonen M, Elomaa I, Isolak J, FinHer Study Investigators: Adjuvant docetaxel or vinorelbine with or without trastuzumab for breast cancer. N Engl J Med 2006, 354:809-820

3. Prat A, Baselga J: The role of hormonal therapy in the management of hormonal-receptor-positive breast cancer with co-expression of HER2. Nat Clin Pract Oncol 2008, 5:531-542.
4. Vogel $\mathrm{CL}$, Cobleigh MA, Tripathy D, Gutheil JC, Harris LN, Fehrenbacher L, Slamon DJ, Murphy M, Novotny WF, Burchmore M, Shak S, Stewart SJ, Press M: Efficacy and safety of trastuzumab as a single agent in first-line treatment of HER2-overexpressing metastatic breast cancer. J Clin Oncol 2002, 20:719-726.

5. Mano MS, Rosa DD, De Azambuja E, Ismael GF, Durbecq V: The 17q12-q21 amplicon: Her2 and topoisomerase-lla and their importance to the biology of solid tumours. Cancer Treat Rev 2007, 33:64-77.

6. Brase JC, Schmidt M, Fischbach T, Sültmann H, Bojar H, Koelbl H, Hellwig B, Rahnenführer J, Hengstler JG, Gehrmann MC: ERBB2 and TOP2A in breast cancer: a comprehensive analysis of gene amplification, RNA levels, and protein expression and their influence on prognosis and prediction. Clin Cancer Res 2010, 16:2391-2401.

7. Arriola E, Rodriguez-Pinilla SM, Lambros MB, Jones RL, James M, Savage K, Smith IE, Dowsett M, Reis-Filho JS: Topoisomerase II a amplification may predict benefit from adjuvant anthracyclines in HER2 positive early breast cancer. Breast Cancer Res Treat 2007, 106:181-189.

8. Di Leo A, Gancberg D, Larsimont D, Tanner M, Jarvinen T, Rouas G, Dolci S, Leroy JY, Paesmans M, Isola J, Piccart MJ: HER-2 amplification and topoisomerase lla gene aberrations as predictive markers in nodepositive breast cancer patients randomly treated either with an anthracycline-based therapy or with cyclophosphamide, methotrexate, and 5-fluorouracil. Clin Cancer Res 2002, 8:1107-1116.

9. Knoop AS, Knudsen H, Balslev E, Rasmussen BB, Overgaard J, Nielsen KV, Schonau A, Gunnarsdóttir K, Olsen KE, Mouridsen H, Ejlertsen B, Danish Breast Cancer Cooperative Group: Retrospective analysis of topoisomerase Ila amplifications and deletions as predictive markers in primary breast cancer patients randomly assigned to cyclophosphamide, methotrexate, and fluorouracil or cyclophosphamide, epirubicin, and fluorouracil: Danish Breast Cancer Cooperative Group. J Clin Oncol 2005, 23:7483-7490.

10. Tanner M, Isola J, Wiklund T, Erikstein B, Kellokumpu-Lehtinen P, Malmström P, Wilking N, Nilsson J, Bergh J: Topoisomerase lla gene amplification predicts favorable treatment response to tailored and dose-escalated anthracycline-based adjuvant chemotherapy in HER-2/ neu-amplified breast cancer: Scandinavian Breast Group Trial 9401. J Clin Oncol 2006, 24:2428-2436.

11. Coon JS, Marcus E, Gupta-Burt S, Seelig S, Jacobson K, Chen S, Renta V, Fronda G, Preisler HD: Amplification and overexpression of topoisomerase lla predict response to anthracycline-based therapy in locally advanced breast cancer. Clin Cancer Res 2002, 8:1061-1067.

12. Park K, Kim J, Lim S, Han S: Topoisomerase II-a (topoll) and HER2 amplification in breast cancers and response to preoperative doxorubicin chemotherapy. Eur J Cancer 2003, 39:631-634.

13. Ejlertsen $B$, Jensen MB, Nielsen $K V$, Balslev E, Rasmussen BB, Willemoe GL, Hertel PB, Knoop AS, Mouridsen HT, Brünner N: HER2, TOP2A, and TIMP-1 and responsiveness to adjuvant anthracycline-containing chemotherapy in high-risk breast cancer patients. J Clin Oncol 2010, 28:984-990.

14. O'Malley FP, Chia S, Tu D, Shepherd LE, Levine MN, Bramwell VH, Andrulis IL, Pritchard KI: Topoisomerase II a and responsiveness of breast cancer to adjuvant chemotherapy. J Natl Cancer Inst 2009, 101:644-650.

15. Villman K, Sjöström J, Heikkilä R, Hultborn R, Malmström P, Bengtsson NO, Söderberg M, Saksela E, Blomqvist C: TOP2A and HER2 gene amplification as predictors of response to anthracycline treatment in breast cancer. Acta Oncol 2006, 45:590-596.

16. Cardoso F, Durbecq V, Larsimont D, Paesmans M, Leroy JY, Rouas G, Sotiriou C, Renard N, Richard V, Piccart MJ, Di Leo A: Correlation between complete response to anthracycline-based chemotherapy and topoisomerase II-a gene amplification and protein overexpression in locally advanced/metastatic breast cancer. Int J Oncol 2004, 24:201-209.

17. Järvinen TA, Tanner M, Rantanen V, Bärlund M, Borg A, Grénman S, Isola J: Amplification and deletion of topoisomerase Ila associate with ErbB-2 amplification and affect sensitivity to topoisomerase II inhibitor doxorubicin in breast cancer. Am J Pathol 2000, 156:839-847.

18. Konecny GE, Pauletti G, Untch M, Wang HJ, Möbus V, Kuhn W, Thomssen C, Harbeck N, Wang L, Apple S, Jänicke F, Slamon DJ: Association between HER2, TOP2A, and response to anthracycline-based preoperative chemotherapy in high-risk primary breast cancer. Breast Cancer Res Treat 2010, 120:481-489.

19. Harris $L N$, Broadwater $G$, Abu-Khalaf M, Cowan D, Thor AD, Budman D, Cirrincione CT, Berry DA, Winer EP, Hudis CA, Hayes DF, Friedman P, Ellis M, Dressler $\mathrm{L}$ : Topoisomerase lla amplification does not predict benefit from 
dose-intense cyclophosphamide, doxorubicin, and fluorouracil therapy in HER2-amplified early breast cancer: results of CALGB 8541/150013. J Clin Oncol 2009, 27:3430-3436.

20. Tubbs R, Barlow WE, Budd GT, Swain E, Porter P, Gown A, Yeh IT, Sledge G, Shapiro C, Ingle J, Haskell C, Albain KS, Livingston R, Hayes DF: Outcome of patients with early-stage breast cancer treated with doxorubicin-based adjuvant chemotherapy as a function of HER2 and TOP2A status. J Clin Oncol 2009, 27:3881-3886.

21. Pritchard KI, Messersmith H, Elavathil L, Trudeau M, O'Malley F, DhesyThind B: HER-2 and topoisomerase II as predictors of response to chemotherapy. J Clin Oncol 2008, 26:736-744.

22. Slamon DJ, Press MF: Alterations in the TOP2A and HER2 genes: association with adjuvant anthracycline sensitivity in human breast cancers. J Natl Cancer Inst 2009, 101:615-618.

23. Kauraniemi $P$, Kuukasjärvi T, Sauter $G$, Kallioniemi A: Amplification of a 280kilobase core region at the ERBB2 locus leads to activation of two hypothetical proteins in breast cancer. Am J Pathol 2003, 163:1979-1984.

24. Arriola E, Marchio C, Tan DS, Drury SC, Lambros MB, Natrajan R, RodriguezPinilla SM, Mackay A, Tamber N, Fenwick K, Jones C, Dowsett M, Ashworth A, Reis-Filho JS: Genomic analysis of the HER2/TOP2A amplicon in breast cancer and breast cancer cell lines. Lab Invest 2008, 88:491-503.

25. Shadeo A, Lam WL: Comprehensive copy number profiles of breast cancer cell model genomes. Breast Cancer Res 2006, 8:R9.

26. Orsetti B, Nugoli M, Cervera N, Lasorsa L, Chuchana P, Ursule L, Nguyen C, Redon R, du Manoir S, Rodriguez C, Theillet C: Genomic and expression profiling of chromosome 17 in breast cancer reveals complex patterns of alterations and novel candidate genes. Cancer Res 2004, 64:6453-6460

27. Glynn RW, Miller N, Kerin MJ: 17q12-21: the pursuit of targeted therapy in breast cancer. Cancer Treat Rev 2010, 36:224-229.

28. Lamy PJ, Nanni I, Fina F, Bibeau F, Romain S, Dussert C, Penault Llorca F Grenier J, Ouafik LH, Martin PM: Reliability and discriminant validity of HER2 gene quantification and chromosome 17 aneusomy analysis by real-time PCR in primary breast cancer. Int I Biol Markers 2006, 21:20-29.

29. Baehner FL, Achacoso N, Maddala T, Shak S, Quesenberry CP Jr, Goldstein LC, Gown AM, Habel LA: Human epidermal growth factor receptor 2 assessment in a case-control study: comparison of fluorescence in situ hybridization and quantitative reverse transcription polymerase chain reaction performed by central laboratories. J Clin Oncol 2010, 28:4300-4306

30. Susini T, Bussani C, Marini G, Nori J, Olivieri S, Molino C, Bianchi S, Vezzosi V, Paglierani M, Giachi M, Borrani E, Scarselli G: Preoperative assessment of HER-2/neu status in breast carcinoma: the role of quantitative real-time PCR on core-biopsy specimens. Gynecol Oncol 2010, 116:234-239.

31. Vranic S, Teruya B, Repertinger S, Ulmer P, Hagenkord J, Gatalica Z: Assessment of HER2 gene status in breast carcinomas with polysomy of chromosome 17. Cancer 2011, 117:48-53.

32. Murthy SK, Magliocco AM, Demetrick DJ: Copy number analysis of c-erb-B2 (HER-2/neu) and topoisomerase lla genes in breast carcinoma by quantitative real-time polymerase chain reaction using hybridization probes and fluorescence in situ hybridization. Arch Pathol Lab Med 2005, 129:39-46.

33. Salido M, Tusquets I, Corominas JM, Suarez M, Espinet B, Corzo C, Bellet M, Fabregat $X$, Serrano $S$, Solé F: Polysomy of chromosome 17 in breast cancer tumors showing an overexpression of ERBB2: a study of 175 cases using fluorescence in situ hybridization and immunohistochemistry. Breast Cancer Res 2005, 7:R267-R273.

34. Bartlett JM, Munro AF, Dunn JA, McConkey C, Jordan S, Twelves CJ, Cameron DA, Thomas J, Campbell FM, Rea DW, Provenzano E, Caldas C, Pharoah P, Hiller L, Earl H, Poole CJ: Predictive markers of anthracycline benefit: a prospectively planned analysis of the UK National Epirubicin Adjuvant Trial (NEAT/BR9601). Lancet Oncol 2010, 11:266-274.

35. Ellsworth RE, Ellsworth DL, Patney HL, Deyarmin B, Love B, Hooke JA, Shriver CD: Amplification of HER2 is a marker for global genomic instability. BMC Cancer 2008, 8:297.

36. Nielsen KV, Müller S, Møller S, Schønau A, Balslev E, Knoop AS, Ejlertsen B: Aberrations of ERBB2 and TOP2A genes in breast cancer. Mol Oncol 2010, 4:161-168.

37. Katoh M, Katoh M: MGC9753 gene, located within PPP1R1B-STARD3ERBB2-GRB7 amplicon on human chromosome 17q12, encodes the seven-transmembrane receptor with extracellular six-cystein domain. Int J Oncol 2003, 22:1369-1374

38. Beroukhim R, Mermel CH, Porter D, Wei G, Raychaudhuri S, Donovan J, Barretina J, Boehm JS, Dobson J, Urashima M, McHenry KT, Pinchback RM,
Ligon AH, Cho YJ, Haery L, Greulich H, Reich M, Winckler W, Lawrence MS, Weir BA, Tanaka KE, Chiang DY, Bass AJ, Loo A, Hoffman C, Prensner J, Liefeld T, Gao Q, Yecies D, Signoretti S, et al: The landscape of somatic copy-number alteration across human cancers. Nature 2010, 463:899-905.

39. Kuwahara Y, Tanabe C, Ikeuchi T, Aoyagi K, Nishigaki M, Sakamoto H, Hoshinaga K, Yoshida T, Sasaki H, Terada M: Alternative mechanisms of gene amplification in human cancers. Genes Chromosomes Cancer 2004, 41:125-132.

40. Kwei KA, Kung Y, Salari K, Holcomb IN, Pollack JR: Genomic instability in breast cancer: pathogenesis and clinical implications. Mol Oncol 2010, 4:255-266.

41. Albertson DG: Gene amplification in cancer. Trends Genet 2006, 22:447-455.

42. Di Leo A, Desmedt C, Bartlett JM, Ejlertsen B, Pritchard KI, Poole CJ, Larsimont D, Tanner M, Piette F, Buyse ME: Final results of a meta-analysis testing HER2 and topoisomerase lla genes as predictors of incremental benefit from anthracyclines in breast cancer [abstract]. J Clin Oncol 2010, 28(15 Suppl):519.

43. Di Leo A, Biganzoli L, Claudino W, Licitra S, Pestrin M, Larsimont D: Topoisomerase lla as a marker predicting anthracyclines' activity in early breast cancer patients: ready for the primetime? Eur J Cancer 2008, 44:2791-2798.

44. Press MF, Sauter G, Buyse ME, Bernstein L, Guzman R, Santiago A, Villalobos IE, Eiermann W, Pienkowski T, Martin M, Robert N, Crown J, Bee V, Taupin H, Flom K, Tabah-Fisch I, Pauletti G, Lindsay MA, Riva A, Slamon DJ: Alteration of Topoisomerase II-Alpha Gene in Human Breast Cancer: Association With Responsiveness to Anthracycline-Based Chemotherapy. $J$ Clin Oncol 2010, in press.

45. Zhu Y, Qi C, Jain S, Rao MS, Reddy JK: Isolation and characterization of PBP, a protein that interacts with peroxisome proliferator-activated receptor. J Biol Chem 1997, 272:25500-25506.

46. Warnmark A, Almlof T, Leers J, Gustafsson JA, Treuter E: Differential recruitment of the mammalian mediator subunit TRAP220 by estrogen receptors ERa and ERß.J Biol Chem 2001, 276:23397-23404.

47. Wu Q, Burghardt R, Safe S: Vitamin D-interacting protein 205 (DRIP205) coactivation of estrogen receptor a $(E R a)$ involves multiple domains of both proteins. J Biol Chem 2004, 279:53602-53612.

48. Staaf J, Jönsson $G$, Ringnér M, Vallon-Christersson J, Grabau D, Arason A, Gunnarsson H, Agnarsson BA, Malmström PO, Johannsson OT, Loman N, Barkardottir RB, Borg A: High-resolution genomic and expression analyses of copy number alterations in HER2-amplified breast cancer. Breast Cancer Res 2010, 12:R25.

49. Järvinen TA, Tanner M, Barlund M, Borg A, Isola J: Characterization of topoisomerase II a gene amplification and deletion in breast cancer. Genes Chromosomes Cancer 1999, 26:142-150.

50. Corzo C, Bellosillo B, Corominas JM, Salido M, Coll MD, Serrano S, Albanell J, Solé $F$, Tusquets I: Does polysomy of chromosome 17 have a role in ERBB2 and topoisomerase lla expression? Gene, mRNA and protein expression: a comprehensive analysis. Tumour Biol 2007, 28:221-228.

51. Esteva FJ, Hortobagyi GN: Topoisomerase lla amplification and anthracycline-based chemotherapy: the jury is still out. J Clin Oncol 2009, 27:3416-3417.

52. Paik S, Bryant J, Park C, Fisher B, Tan-Chiu E, Hyams D, Fisher ER, Lippman ME, Wickerham DL, Wolmark N: erbB-2 and response to doxorubicin in patients with axillary lymph node-positive, hormone receptor-negative breast cancer. J Natl Cancer Inst 1998, 90:1361-1370

53. Pritchard KI, Shepherd LE, O'Malley FP, Andrulis IL, Tu D, Bramwell VH, Levine MN: HER2 and responsiveness of breast cancer to adjuvant chemotherapy. N Engl J Med 2006, 354:2103-2111.

54. Gennari A, Sormani MP, Pronzato P, Puntoni M, Colozza M, Pfeffer U, Bruzzi P: HER2 status and efficacy of adjuvant anthracyclines in early breast cancer: a pooled analysis of randomized trials. I Natl Cancer Inst 2008, 100:14-20.

55. NCBI Sequence Viewer version 2.10. [http://www.ncbi.nlm.nih.gov/ projects/sviewer/].

\section{doi:10.1186/bcr2824}

Cite this article as: Lamy et al:: Quantification and clinical relevance of gene amplification at chromosome 17q12-q21 in human epidermal growth factor receptor 2-amplified breast cancers. Breast Cancer Research 2011 13:R15. 